\title{
The Medicinal Timber Canarium patentinervium Miq. (Burseraceae Kunth.) Is an Anti-Inflammatory Bioresource of Dual Inhibitors of Cyclooxygenase (COX) and 5-Lipoxygenase (5-LOX)
}

\author{
R. Mogana, K. Teng-Jin, and C. Wiart \\ Center for Natural and Medicinal Products Research, School of Pharmacy, Faculty of Science, \\ University of Nottingham (Malaysia Campus), Jln Broga, 43500 Semenyih, Selangor Darul Ehsan, Malaysia
}

Correspondence should be addressed to R. Mogana; khyxlmsa@nottingham.edu.my

Received 10 July 2013; Accepted 19 August 2013

Academic Editors: A. O. Ballesteros, A. Maggio, and D. Pant

Copyright (C) 2013 R. Mogana et al. This is an open access article distributed under the Creative Commons Attribution License, which permits unrestricted use, distribution, and reproduction in any medium, provided the original work is properly cited.

\begin{abstract}
The barks and leaves extracts of Canarium patentinervium Miq. (Burseraceae Kunth.) were investigated for cyclooxygenase (COX) and 5-lipoxygenase (LOX) inhibition via in vitro models. The corresponding antioxidative power of the plant extract was also tested via nonenzyme and enzyme in vitro assays. The ethanolic extract of leaves inhibited the enzymatic activity of 5-LOX, COX-1, and COX-2 with $\mathrm{IC}_{50}$ equal to $49.66 \pm 0.02 \mu \mathrm{g} / \mathrm{mL}, 0.60 \pm 0.01 \mu \mathrm{g} / \mathrm{mL}$, and $1.07 \pm 0.01 \mu \mathrm{g} / \mathrm{mL}$, respectively, with selective COX-2 activity noted in ethanolic extract of barks with COX-1/COX-2 ratio of 1.22. The ethanol extract of barks confronted oxidation in the ABTS, $\mathrm{DPPH}$, and FRAP assay with $\mathrm{EC}_{50}$ values equal to $0.93 \pm 0.01 \mu \mathrm{g} / \mathrm{mL}, 2.33 \pm 0.02 \mu \mathrm{g} / \mathrm{mL}$, and $67.00 \pm 0.32 \mu \mathrm{g} / \mathrm{mL}$, respectively, while the ethanol extract of leaves confronted oxidation in $\beta$-carotene bleaching assay and superoxide dismutase (SOD) assay with $\mathrm{EC}_{50}$ value of $6.04 \pm 0.02 \mu \mathrm{g} / \mathrm{mL}$ and $\mathrm{IC}_{50}$ value of $3.05 \pm 0.01 \mu \mathrm{g} / \mathrm{mL}$. The ethanol extract acts as a dual inhibitor of LOX and COX enzymes with potent antioxidant capacity. The clinical significance of these data is quite clear that they support a role for Canarium patentinervium Miq. (Burseraceae Kunth.) as a source of lead compounds in the management of inflammatory diseases.
\end{abstract}

\section{Introduction}

Inflammation is a physiological response process that is generated by the body in the event of oxidative stress, injury, infection, or irritation. Chronic inflammation involves the release of a number of mediators, resulting in the proliferation of fibroblasts and vascular endothelium, as well as lymphocytes, plasma cells, and macrophages [1]. The release of all these mediators can contribute to chronic degenerative diseases such as arthritis, cancer, heart disease, Alzheimer's disease, diabetes, and asthma, which may increase diseaseassociated morbidity. Inflammation in injured cells is both initiated and maintained by the overproduction of prostaglandins and leukotrienes, which are produced by separate enzymatic pathways, namely, the cyclooxygenase (COX) and lipoxygenase (LOX) pathways, respectively. Both the prostaglandins as well as the leukotrienes are on demand biosynthesised from arachidonic acid (AA), which is a 20 -carbon fatty acid, derived from the breakdown of cell membrane phospholipids by any number of phospholipase A2 $\left(\mathrm{PLA}_{2}\right)$ isoforms. AA is then further metabolized by the COX and 5-LOX enzyme systems to a variety of mediator molecules, including prostaglandin (PG) $\mathrm{E}_{2}$, thromboxanes (TXs) $\left(\mathrm{TXA}_{2}\right)$, prostacyclins $\left(\mathrm{PGI}_{2}\right)$, and highly inflammatory leukotrienes such as leukotriene (LT) $\mathrm{B}_{4}, \mathrm{LTC}_{4}$, and $\mathrm{LTD}_{4}$.

Conventional pharmacological management of inflammatory disease like osteoarthritis involves treatment with nonsteroidal anti-inflammatory drugs (NSAIDs) or selective COX-2 inhibitors that block the formation of PGs without modulating 5-LOX enzyme activity. Inhibition of one or both of the COX enzymes may "shunt" AA metabolism down the 5-LOX pathway, which can aggravate toxicity associated with the lack of PGs and excess production of LTs. For 
example, NSAID-induced gastric ulcers have been shown to have high concentrations of $\mathrm{LTB}_{4}$ in their walls, which attract leukocytes to the stomach and may contribute to ulceration $[2,3]$.

Recently, reports have appeared regarding so-called "dual inhibitors," agents that inhibit not only COX-1 and COX-2 but also 5-LOX [4-8]. These agents with antioxidative properties may be particularly effective for managing the metabolic processes underlying inflammatory conditions and reducing both gastric and cardiovascular side effects by balancing AA metabolism in the body.

In continuation of our earlier studies on the pharmacological properties of Canarium patentinervium Miq. that established its in vitro antibacterial, antioxidant, and antitumor activity [9-11], this study investigates the inhibition of 5LOX, COX-I, and COX-2 and the total antioxidant capacity of Canarium patentinervium Miq. Canarium patentinervium Miq. is a rare medicinal timber from the genus Canarium and family of Burseraceae found in Asia Pacific region previously recorded for its usage in wound healing by the indigenous people $[11,12]$. The above dual inhibition study by our team is the first documented study reported on this plant.

\section{Materials and Methods}

2.1. Plant Material. The leaves and barks of Canarium patentinervium Miq. were collected from one individual tree from Bukit Putih, Selangor, Malaysia $\left(3^{\circ} 5^{\prime} 24^{\prime \prime} \mathrm{N} 101^{\circ} 46^{\prime} 0^{\prime \prime} \mathrm{E}\right)$. The plant was identified by Mr. Kamaruddin (Forest Research Institute of Malaysia). A herbarium sample (PID 25121012) has been deposited in the Forest Research Institute of Malaysia. The leaves were air-dried and grinded into small particles using an industrial grinder.

2.2. Chemical and Reagents. 1,1-diphenyl-2-picryhydrazyl (DPPH), Trolox (6-hydroxy-2,5,7,8-tetramethylchromon2-carboxylic acid), 2,2-azino-bis(3-thylbenzothiazoline-6sulfonate), 2,4,6-tripyridyl-s-triazine (TPTZ), quercetin, gallic acid, $\beta$-carotene, 5,5'-Dithio-bis(2-nitrobenzoic) acid (DTNB), galantamine, nordihydroguaiaretic acid (NDGA), Folin-Ciocalteu reagent, bovine hemin chloride, $N, N, N^{\prime}, N^{\prime}$ tetramethyl-p-phenylenediamine dihydrochloride (TMPD), Tris-CL, and SOD kit were purchased from Sigma Aldrich. Sodium chloride, ascorbic acid, ferric chloride, and glacial acetic acid were purchased from System. Hexane and chloroform were purchased from Friendemann Schmidt Chemicals. Methanol and ethanol 95\%, potassium persulfate powder, ferric chloride, ferrous sulphate, Tween 20, and potassium phosphate were purchased from Kollin Chemicals. DMSO was from $\mathrm{R} \& \mathrm{M}$ Marketing, Essex UK. Linoleic acid, AA, superoxide dismutase (SOD), COX-1, and COX-2 were purchased from Cayman Chemical Company. Enzyme 5-lipoxygenase enzyme (human recombinant) was purchased from Calbiochem.

2.3. Extraction. Dried and grinded sample of leaves $(2.8 \mathrm{~kg})$ were soaked in hexane with the ratio of $1: 3$ parts $(w / v)$ of sample to solvent for $2 \mathrm{~h}$ in a $60^{\circ} \mathrm{C}$ water bath and then filtered and concentrated with a rotary evaporator (Buchi, R200 Switzerland). This was repeated three times. Thereafter the leaves and barks were left to air dry completely for three days before repeating the whole process with chloroform and then ethanol, respectively. Extracts were kept at $-20^{\circ} \mathrm{C}$ until further use. The extracts were indicated as LH (leaf hexane extract), LC (leaf chloroform extract), LE (leaf ethanol extract), BH (bark hexane extract), BC (bark chloroform extract), and BE (bark ethanol extract), respectively.

2.4. Determination of Total Phenolic and Total Flavonoid of Extracts. The total phenolic content of the extracts was determined with the Folin-Ciocalteu reagent, following the modified method of Singleton and Rossi [13]. Briefly, $20 \mu \mathrm{L}$ of test samples dissolved in methanol $(1 \mathrm{mg} / \mathrm{mL})$ was added to $100 \mu \mathrm{L}$ of Folin-Ciocalteu reagent and $1.58 \mathrm{~mL}$ of deionised water. After allowing the mixture to stand at room temperature for $5 \mathrm{~min}, 300 \mu \mathrm{L}$ of $20 \%$ (w/v) sodium carbonate was added. Reaction mixtures were further incubated at room temperature for 30 mins, following which absorbance at $765 \mathrm{~nm}$ was read against a blank, using a Jenway $6305 \mathrm{UV}$ Vis spectrophotometer (Jenway Ltd., Essex, UK). The standard calibration curve was plotted using gallic acid (50$250 \mu \mathrm{g} / \mathrm{mL}$ ), from which total phenolic content was expressed as gallic acid equivalents ( $\mathrm{mg} / \mathrm{g}$ extract). The total flavonoid content of the crude extract was determined with the aluminium chloride colorimetric method of Froehlicher et al. [14]. Briefly, $0.5 \mathrm{~mL}$ of test samples dissolved in methanol $(1 \mathrm{mg} / \mathrm{mL})$ was added to $1.5 \mathrm{~mL}$ of $2 \%$ methanolic solution of aluminium chloride in sealed tubes and kept in dark for 15 mins. Absorbance was then read at $430 \mathrm{~nm}$ using UV-vis spectrophotometer against blank of methanolic aluminium chloride solution. The standard calibration curve was plotted using quercetin $(50-250 \mu \mathrm{g} / \mathrm{mL})$, from which total flavonoid content was expressed as quercetin equivalents (mg/g extract).

2.5. Antioxidant Capacity Tests. Aliquots of extracts were dissolved in dimethyl sulfoxide (DMSO, R \& M) prior to assay. Trolox, vitamin C (1-ascorbic acid), and quercetin were used as positive control. The positive controls were indicated as AA (ascorbic acid), QC (quercetin), TRO (trolox), and SOD (superoxide dismutase enzyme), respectively. Assay was performed using Thermo Scientific Varioskan Flash microtiter plate reader, linked to a computer equipped with (SkanIt Software 2.4.3). EC E0 $_{\text {(concentration of a compound }}$ where $50 \%$ of its maximal effect is observed) values were determined using Prism 5.00 software. At least three independent tests were performed for each sample. All results were calculated after correcting for colour absorbance of the plant extract as sample blank.

2.5.1. 2,2-Azino-bis(3-thylbenzothiazoline-6-sulfonate) (ABTS) Assay. The ABTS assay, as described by Miller et al. [15], RiceEvans [16], and Re et al. [17], was employed to determine the radical scavenging activity of the plant extracts. ABTS assay involves the reduction of the blue-green 2,2-azino-bis(3thylbenzothiazoline-6-sulfonate) radical cation $\left(\mathrm{ABTS}^{\circ+}\right)$ by antioxidants to its original colourless ABTS form. Greater 
discolouration results in lower absorbance at $734 \mathrm{~nm}$ indicating higher antioxidant capacity $[15,16]$. Samples were plated out in triplicate in 96-well microtiter plate at different concentrations. Trolox, vitamin C (l-ascorbic acid), and quercetin were used as positive control which was prepared in ethanol, and serial dilutions of this positive control were also prepared. Ethanol was used as the negative control. The stock solution included $7 \mathrm{mM}$ ABTS solution and $2.4 \mathrm{mM}$ potassium persulfate solution. The working solution was then prepared by mixing the two stock solutions in equal quantities. This solution was then stored in the dark for 12-16 hours in order to stabilise it before use. It remains stable for two to three days in the dark. The concentrated ABTS+ solution was diluted with cold ethanol shortly before conducting the assay, to a final absorbance of $0.70 \pm 0.01$ at $734 \mathrm{~nm}$ at $37^{\circ} \mathrm{C}$, in a $3 \mathrm{~cm}$ cuvette. The total scavenging capacity of the extracts was quantified through the addition of $100 \mu \mathrm{L}$ ABTS+ to $100 \mu \mathrm{L}$ of test sample. The solutions were heated to $37^{\circ} \mathrm{C}$ for $7 \mathrm{~min}$, after which the absorbance was read at $734 \mathrm{~nm}$. The percentage decolouration was calculated using the following equation, and the extent of inhibition of the absorbance of the ABTS + was plotted as a function of the concentration. This activity is given as percent ABTS radical scavenging, which is calculated with the equation: ABTS radical scavenging capacity $(\%)=\left[\left(A_{\text {control }}-A_{\text {sample }}\right) /\left(A_{\text {control }}\right)\right] \times 100$, where $A_{\text {control }}$ is the absorbance of ABTS radical + ethanol; $A_{\text {sample }}$ is the absorbance of ABTS radical + sample extract/standard. Sample well with ethanol devoid of ABTS was used as ABTS blank control to correct colour absorbance of samples.

2.5.2. Ferric Reducing Ability of Plasma (FRAP) Assay. The antioxidant activity samples were determined using the colorimetric FRAP assay, as described by Benzie and Strain [18] with slight modifications. FRAP is the ferric reducing power of antioxidants by the reduction of the ferric ions to the ferrous ions, which form a blue colored ferroustripyridyltriazine complex (ferric TPTZ) which is detected at $593 \mathrm{~nm}$. Deeper blue colour indicates higher antioxidant potential [19]. Aliquots of samples were plated out in triplicate in a 96-well microtiter plate at different concentrations. The working FRAP reagent was prepared just before assay by mixing $300 \mathrm{mM}$ of acetate buffer ( $\mathrm{pH} \mathrm{3.6),} 10 \mathrm{mM}$ of TPTZ, and $20 \mathrm{mM}$ of $\mathrm{FeCl}_{3} \cdot 6 \mathrm{H}_{2} \mathrm{O}$ in ratio of $10: 1: 1$. Briefly $180 \mu \mathrm{L}$ of the FRAP reagent was mixed with $20 \mu \mathrm{L}$ of the test sample so that the final dilution of the test sample in the reaction mixture was 1/10. After 30 minutes, the absorbance of the coloured product (ferrous tripyridyltriazine complex) was recorded. Fe (II) concentrations in the range of $1 \mu \mathrm{M}-100 \mu \mathrm{M}$ $\left(\mathrm{FeSO}_{4} \cdot 7 \mathrm{H}_{2} \mathrm{O}\right)$ were used as standard for calibration curve, and equation of linearity is determined $(y=a x+b)$. From the linearity equation, concentration of sample that produced the same absorbance as $1 \mathrm{mM}$ of Fe (II) was determined ( $y$ of sample filled in equation to obtain $x$ ). The antioxidant activity was calculated as ferrous equivalents, the concentration of samples which produced an absorbance value equal to that of $1 \mathrm{mM} \mathrm{FeSO}_{4}$. Sample well without FRAP reagent was used as sample blank control to correct colour absorbance of samples.
2.5.3. $\beta$-Carotene Bleaching Assay. The $\beta$-carotene bleaching assay was conducted according to the method described by Habtemariam and Jackson [20] with some modifications. In the $\beta$-carotene/linoleic model, linoleic acid reacts with ROS (reactive oxygen species, i.e., chemically reactive molecules containing oxygen) and $\mathrm{O}_{2}$ to form an unstable peroxy radical. $\beta$-carotene being an antioxidant will react with this radical to form stable epoxide causing the bleaching of yellow solution. Competition reaction occurs with the presence of another antioxidant (sample) to react with the peroxy radical resulting in slower bleaching of solution detected at $470 \mathrm{~nm}$ spectrophotometrically [21]. Aliquots of samples were plated out in triplicate in a 96-well microtiter plate at different concentrations. Briefly, $1 \mathrm{~mL}$ of a $\beta$-carotene solution in chloroform $(2 \mathrm{mg}$ in $10 \mathrm{~mL})$ was pipetted into a round bottom flask containing $40 \mu \mathrm{L}$ of linoleic acid and $500 \mu \mathrm{L}$ of Tween 20. After the removal of chloroform using a rotary vacuum evaporator at $45^{\circ} \mathrm{C}, 100 \mathrm{~mL}$ of deionised water was added with vigorous agitation. $180 \mu \mathrm{L}$ of the emulsion was added to $20 \mu \mathrm{L}$ of test samples at varying concentrations in 96-well microtitre plate. The absorbance was measured at $470 \mathrm{~nm}$ immediately against a blank consisting of the emulsion without $\beta$-carotene and after $3 \mathrm{~h}$ of incubation at $50^{\circ} \mathrm{C}$ using a spectrophotometer. The antioxidant activity of test agents was evaluated in terms of bleaching of $\beta$ carotene using the following formula: Antioxidant activity $\operatorname{AA}(\%)=\left[1-\left(A_{0}-A_{t}\right) /\left(A_{0}^{\prime}-A_{t}^{\prime}\right)\right] \times 100$, where $A_{0}$ and $A_{0}^{\prime}$ are absorbances measured at zero time of incubation for the test sample and control, respectively; $A_{t}$ and $A_{t}^{\prime}$ are the absorbances measured in the test sample and control, respectively, after incubation for $3 \mathrm{~h}$. Sample well without $\beta$ carotene was used as sample blank control to correct colour absorbance of samples.

2.5.4. Superoxide Dismutase (SOD) Assay. This assay was conducted with Sigma SOD assay kit [22]. SOD Assay Kit-WST allows very convenient SOD assaying by utilizing Dojindo's highly water-soluble tetrazolium salt, WST-1 (2-(4-Iodophenyl)-3-(4-nitrophenyl)-5-(2,4-disulfophenyl)$2 \mathrm{H}$-tetrazolium, monosodium salt), that produces a watersoluble formazan dye upon reduction with a superoxide anion. In this study the enzymatic system that uses xanthine oxidase (XOD) to generate $\mathrm{O}_{2}{ }^{-}$radicals was used [23]. XOD was used for formation of $\mathrm{O}_{2}{ }^{-}$that is reduced to oxygen by SOD-like samples. The WST-1 is used as a probe that undergoes competitive reaction with SOD-like samples to reduce $\mathrm{O}_{2}{ }^{-}$to oxygen forming a formazan coloured dye. The rate of reduction with oxygen is linearly related to the xanthine oxidase (XO) activity and is inhibited by SOD. Therefore, the $\mathrm{IC}_{50}$ (50\% inhibition activity of SOD or SOD-like materials) can be determined by a colorimetric method. Since the absorbance at $450 \mathrm{~nm}$ is proportional to the amount of superoxide anion, the SOD activity as an inhibition activity can be quantified by measuring the decrease in the colour development at $450 \mathrm{~nm}$. Twenty microliters of sample were plated at different concentrations in a 96-well microtiter plate. Then, $200 \mu \mathrm{L}$ of WST solution and $20 \mu \mathrm{L}$ of enzyme were added and incubated for $20 \mathrm{mins}$ 
at $37^{\circ} \mathrm{C}$. Absorbance was then recorded at $450 \mathrm{~nm}$ using Thermo Scientific Varioskan Flash microtiter plate reader, linked to a computer equipped with (SkanIt Software 2.4.3). The SOD inhibition rate and $\mathrm{IC}_{50}$ (concentration of a compound that is required for $50 \%$ inhibition in vitro) were determined. Superoxide dismutase enzyme (Nacalai Tesque) was used as standard control. Sample well with buffer was used as sample blank control to correct colour absorbance of samples.

2.6. The 5-LOX Inhibition Assay. The 5-lipoxygenase assay was conducted according to the method described by Baylac and Racine [24] and Kamatou et al. [25] with some modifications. 5-lipoxygenase enzyme (human recombinant from Calbiochem) was used. Ice-cold buffer (potassium phosphate) at $4^{\circ} \mathrm{C}$ was mixed with $100 \mathrm{U}$ of the thawed enzyme. Twenty microliters of samples dissolved in DMSO were plated out in triplicate in a 96-well microtiter plate at different concentrations, followed by $160 \mu \mathrm{L}$ of $0.1 \mathrm{M}$ potassium phosphate buffer $(\mathrm{pH}$ 6.3) and maintained at $25^{\circ} \mathrm{C}$ and $20 \mu \mathrm{L}$ of enzyme solution. Mixture was agitated, and $10 \mu \mathrm{L}$ of linoleic acid was added and incubated for 10 mins at $25^{\circ} \mathrm{C}$. Absorbance was recorded at $234 \mathrm{~nm}$ using Thermo Scientific Varioskan Flash microtiter plate reader, linked to a computer equipped with (SkanIt Software 2.4.3). 5-Lipoxygenase is known to catalyse oxidation of unsaturated fatty acids containing 1-4 diene, and the modification of linoleic acid (1-4-diene into 1-3-diene) can be detected at $234 \mathrm{~nm}$. Percentage inhibition of enzyme was determined by comparison of rates of reaction of samples relative to blank sample using the formula: $(E-S) / E \times 100$, where $E$ is the activity of enzyme without test sample and $S$ is the activity of enzyme with test sample. The experiments were done in triplicate. Nordihydroguaiaretic acid (NDGA) was used as positive control. Sample well with buffer was used as sample blank control to correct colour absorbance of samples.

2.7. The Peroxidase Endpoint Assay for COX-1 and COX-2. The COX-1 and COX-2 peroxidase end-point assay was conducted according to the method described by Gierse and Koboldt [26]. COX-1 and COX-2 enzyme from Cayman were used. In this study, COX activity is measured by utilizing peroxidase activity and the electron donor TMPD, which turns blue upon reduction as a cosubstrate. Arachidonic acid is used as a substrate which must first be converted to hydroperoxide, thus yielding an indirect measure of COX activity. This assay has been noted to be a high throughput method [26]. Twenty microliters of sample dissolved in DMSO were plated in triplicates at different concentrations in a 96 -well microtiter plate followed by $20 \mu \mathrm{L}$ of $10 \mathrm{U} / \mathrm{mL}$ of enzyme solution. Then, $160 \mu \mathrm{L}$ of endpoint assay mix consisting of $100 \mu \mathrm{M}$ bovine hemin chloride, $10 \mathrm{mM}$ of $\mathrm{AA}$, $17 \mathrm{mM}$ of TMPD, and $1 \mathrm{M}$ of buffer Tris- $\mathrm{Cl}$ was added and incubated for $10 \mathrm{mins}$ at $25^{\circ} \mathrm{C}$. Absorbance was recorded at $611 \mathrm{~nm}$ using Thermo Scientific Varioskan Flash microtiter plate reader, linked to a computer equipped with (SkanIt Software 2.4.3). Percentage inhibition of enzyme was determined by comparison of rates of reaction of samples relative to blank sample using the formula: $(E-S) / E \times 100$, where
$E$ is the activity of enzyme without test sample and $S$ is the activity of enzyme with test sample. Indomethacin (INDO) was used as positive control. Sample well with buffer was used as sample blank control to correct colour absorbance of samples.

2.8. Statistical Analysis. Concentration-response curves were calculated using the Prism software package 5.00 for Windows, GraphPad Software, San Diego, California, USA, http://www.graphpad.com/ (GraphPad, San Diego, USA), and data were obtained from three independent experiments, each performed in triplicates $(n=9)$ and represented as mean \pm SD. Nonlinear best fit was plotted with mean \pm SD. Oneway ANOVA was performed followed by Tukey's multiple comparison tests. Throughout the analysis, $P<0.05$ was considered significant.

\section{Results and Discussions}

3.1. Extraction Yield, Total Phenolic, and Flavonoid Contents. Table 1 presents the yield and the total phenolic and flavonoid contents of the extracts. The ethanol extract of leaves had the highest yield amongst the six extracts. In the Folin-Ciocalteu assay, gallic acid was used as a standard $(y=0.1762 x+$ $\left.0.0047, r^{2}=0.9994\right)$, and the results were expressed in gallic acid equivalent $(\mathrm{mg} / \mathrm{g})$. The total phenolic contents of the six extracts varied from 6.61 to $204.97 \mathrm{mg} / \mathrm{g}$ extract. The total flavonoid content was evaluated using quercetin as a standard $\left(y=0.0093 x-0.00231 ; r^{2}=0.9992\right.$, with $x$ as the concentration of quercetin in $\mathrm{mg} / \mathrm{mL}$ ). Our study revealed the presence of high amount of phenolic compounds and flavonoid in the ethanol extracts of leaves with value of $204.97 \mathrm{mg} / \mathrm{g}$ GAE and $125.32 \mathrm{mg} / \mathrm{g}$ quercetin equivalent, respectively.

3.2. Antioxidant Capacity. In vitro antioxidant capacity can be determined by hydrogen atom transfer (HAT) method and single electron transfer (SET) method [27]. HAT-based methods measure the ability of an antioxidant to scavenge free radical by hydrogen donation to form a stable compound. SET-based methods detect the ability of the antioxidant to transfer one electron to reduce compound including metals, carbonyls, and radicals $[28,29] . \beta$-carotene bleaching assay involves HAT method, and FRAP assay involves SET method, while DPPH and ABTS assay involve both methods predominantly via SET method $[23,30]$.

Table 2 presents the $\mathrm{EC}_{50}$ values for the respective assays. In the FRAP assay, the samples absorbance equivalent to $1 \mathrm{mM} \mathrm{FeSO}_{4}$ was calculated from equation of linearity of individual sample. Total FRAP value was determined from the absorbance obtained from the samples above using the standard Fe (II) calibration curve equation $(y=0.0105 x+$ 0.0136, $\left.r^{2}=0.9817\right)$. Ethanol extract of barks displayed significant $(P<0.05)$ FRAP value $(67.00 \pm 0.32 \mu \mathrm{g} / \mathrm{mL})$ compared to ascorbic acid $(347.00 \pm 0.23 \mu \mathrm{g} / \mathrm{mL})$ and quercetin $(86.00 \pm 0.24 \mu \mathrm{g} / \mathrm{mL})$. In the $\beta$-carotene bleaching assay, ethanol extract of leaves and barks displayed the best $\mathrm{EC}_{50}$ value of $6.04 \pm 0.02 \mu \mathrm{g} / \mathrm{mL}$ and $7.04 \pm 0.04 \mu \mathrm{g} / \mathrm{mL}$, respectively. 
TABLE 1: Extraction yield and the total phenolic and flavonoid contents of the six extracts of Canarium patentinervium Miq.

\begin{tabular}{lccc}
\hline Extracts & Extraction yield, \% (w/w) & $\begin{array}{c}\text { Total phenolic content, gallic acid } \\
\text { equivalent }(\mathrm{mg} / \mathrm{g})\end{array}$ & $\begin{array}{c}\text { Total flavonoid content, quercetin } \\
\text { equivalent }(\mathrm{mg} / \mathrm{g})\end{array}$ \\
\hline LH & 1.25 & $6.61 \pm 0.01$ & $18.99 \pm 0.02$ \\
LC & 1.11 & $14.28 \pm 0.03$ & $12.57 \pm 0.04$ \\
LE & 6.45 & $204.97 \pm 0.05$ & $125.32 \pm 0.03$ \\
BH & 1.04 & $5.19 \pm 0.01$ & $1.55 \pm 0.02$ \\
BC & 0.40 & $13.99 \pm 0.03$ & $12.14 \pm 0.02$ \\
BE & 2.61 & $100.26 \pm 0.01$ & $24.57 \pm 0.02$ \\
\hline
\end{tabular}

LH: leaf hexane extract, LC: leaf chloroform extract, LE: leaf ethanol extract, BH: bark hexane extract, BC: bark chloroform extract, and BE: bark ethanol extract.

TABle 2: Antioxidant values of Canarium patentinervium Miq.

\begin{tabular}{lcccc}
\hline Extracts & ABTS assay, $\mathrm{EC}_{50}(\mu \mathrm{g} / \mathrm{mL})$ & $\begin{array}{c}\text { FRAP assay, FRAP } \\
\text { value }(\mu \mathrm{g} / \mathrm{mL})\end{array}$ & $\begin{array}{c}\beta \text {-Carotene bleaching } \\
\text { assay, } \mathrm{EC}_{50}(\mu \mathrm{g} / \mathrm{mL})\end{array}$ & $\begin{array}{c}\text { Superoxide dismutase } \\
\text { assay, } \mathrm{IC}_{50}(\mu \mathrm{g} / \mathrm{mL})\end{array}$ \\
\hline LH & $27.30 \pm 0.01$ & $2845.00 \pm 0.15$ & $9.39 \pm 0.05$ & $80.54 \pm 0.03$ \\
LC & $31.10 \pm 0.02$ & $1329.00 \pm 0.18$ & $21.81 \pm 0.04$ & $26.84 \pm 0.03$ \\
LE & $2.28 \pm 0.01$ & $200.00 \pm 0.07$ & $6.04 \pm 0.02$ & $3.05 \pm 0.01$ \\
BH & $521.00 \pm 0.01$ & $3531.00 \pm 0.14$ & $125.00 \pm 0.08$ & $238.00 \pm 0.04$ \\
BC & $34.90 \pm 0.02$ & $1242.00 \pm 0.19$ & $50.40 \pm 0.03$ & $20.13 \pm 0.02$ \\
BE & $0.93 \pm 0.01 \mathrm{a}$ & $67.00 \pm 0.32$ & $7.04 \pm 0.04$ & $8.51 \pm 0.07$ \\
AA & $1.54 \pm 0.06$ & $347.00 \pm 0.23$ & $\mathrm{NA}$ & $\mathrm{NA}$ \\
QC & $0.88 \pm 0.03 \mathrm{a}$ & $86.00 \pm 0.24$ & $1.64 \pm 0.04 \mathrm{~b}$ & $\mathrm{NA}$ \\
TRO & $0.68 \pm 0.02$ & $33.00 \pm 0.54$ & $1.65 \pm 0.03 \mathrm{~b}$ & $\mathrm{NA}$ \\
SOD & $\mathrm{NA}$ & $\mathrm{NA}$ & $\mathrm{NA}$ & $1.59 \pm 0.04$ \\
\hline
\end{tabular}

LH: leaf hexane extract, LC: leaf chloroform extract, LE: leaf ethanol extract, BH: bark hexane extract, BC: bark chloroform extract, BE: bark ethanol extract, AA: ascorbic acid, QC: quercetin, TRO: trolox, and SOD: superoxide dismutase enzyme.

Data were obtained from three independent experiments, each performed in triplicates $(n=9)$ and represented as mean \pm SD.

Values with the same letter are not significantly different $(P<0.05)$ according to Tukey, multiple comparison test.

In the ABTS assay, ethanol extract of the bark displayed significant $(P<0.05) \mathrm{EC}_{50}(0.93 \pm 0.01 \mu \mathrm{g} / \mathrm{mL})$ compared to ascorbic acid $(1.54 \pm 0.06 \mu \mathrm{g} / \mathrm{mL})$. In our previous study of DPPH assay (another SET method), ethanol extract of leaves and barks displayed significantly lower $\mathrm{EC}_{50}$ value of $2.93 \pm$ $0.00 \mu \mathrm{g} / \mathrm{mL}$ and $2.33 \pm 0.02 \mu \mathrm{g} / \mathrm{mL}$, respectively, compared to trolox $\left(\mathrm{EC}_{50}=4.77 \pm 0.04 \mu \mathrm{g} / \mathrm{mL}\right)$ [11]. The DPPH and ABTS assays have the same mechanism of action but, in most cases, the results obtained from the ABTS assay are higher than those from DPPH assay. It has been documented that results reported for the ABTS assay do not only take into account the activity of the parent compound but also the contribution of reaction products and other individual compounds on the activity, which is not the case in the DPPH assay $[31,32]$.

Superoxide dismutase (SOD), which catalyses the dismutation of the superoxide anion $\left(\mathrm{O}_{2}^{-}\right)$into hydrogen peroxide and molecular oxygen, is one of the most important antioxidative enzymes. Preventive antioxidants, such as SOD are described either as preventing introduction of initiating radicals or as inhibiting the rate where new chains are set up. The ethanol extract of the leaves shows the highest SOD-like activity with $\mathrm{IC}_{50}$ of $3.05 \pm 0.01 \mu \mathrm{g} / \mathrm{mL}$.

In the above experiments, the ethanol extract of leaves and barks displayed superior antioxidant capacities. The $\mathrm{EC}_{50}$ values of the samples were consistently low in SET methods
(ABTS, DPPH, and FRAP) superior to standard as opposed to HAT method ( $\beta$-carotene bleaching) assay. The present study demonstrates that Canarium patentinervium Miq. is a potent source of antioxidants that exhibits its antioxidant activity predominantly via the SET method.

Several reports emphasized on the fact that there is a positive relationship between total phenolic contents and antioxidant activity $[33,34]$. Our study demonstrated the existence of a low positive correlation between the total phenolic contents and the FRAP values $(y=-0.0125 x+$ 2.2564, $\left.r^{2}=0.5246\right)$ and total phenolic contents and $\beta$ carotene bleaching values $\left(y=-0.2747 x+52.42, r^{2}=\right.$ $0.2287)$, respectively. Therefore, one could draw an inference that nonphenolic compounds by itself or in synergy with the phenolics and flavonoids impart Canarium patentinervium Miq. its antioxidant properties.

3.3. Anti-Inflammatory Activity. This assay measures the inhibitory activity against 5-LOX and COX enzymes. At the onset of the inflammatory process, arachidonic acid is converted to eicosanoids and leukotriene $\mathrm{B}_{4}\left(\mathrm{LTB}_{4}\right)$ by LOX [35], which is coupled with the production of prostaglandins and thromboxanes by cyclooxygenase (COX). These inflammatory mediators are responsible for the powerful chemoattractive effects on the eosinophils, neutrophils, and macrophages, 
TABLE 3: Anti-inflammatory values of Canarium patentinervium Miq.

\begin{tabular}{lcccc}
\hline Extracts & $\begin{array}{c}\text { Anti-inflammatory assay } \\
\text { 5-LOX, } \mathrm{IC}_{50}(\mu \mathrm{g} / \mathrm{mL})\end{array}$ & $\begin{array}{c}\text { COX-1 inhibition assay } \\
\mathrm{IC}_{50}(\mu \mathrm{g} / \mathrm{mL})\end{array}$ & $\begin{array}{c}\text { COX-2 inhibition assay } \\
\mathrm{IC}_{50}(\mu \mathrm{g} / \mathrm{mL})\end{array}$ & COX-1/COX-2 ratio \\
\hline LH & $206.00 \pm 0.02$ & $>100$ & $>100$ & $\mathrm{NA}$ \\
LC & $104.69 \pm 0.04$ & $>100$ & $1.07 \pm 0.01$ & $\mathrm{NA}$ \\
LE & $49.66 \pm 0.02$ & $0.60 \pm 0.01$ & $>100$ & 0.56 \\
BH & $110.07 \pm 0.04$ & $>100$ & $>100$ & $\mathrm{NA}$ \\
BC & $29.53 \pm 0.03$ & $>100$ & $9.39 \pm 0.03$ & $\mathrm{NA}$ \\
BE & $59.06 \pm 0.07$ & $11.41 \pm 0.03$ & $\mathrm{NA}$ & 1.22 \\
NDGA & $29.19 \pm 0.02$ & $\mathrm{NA}$ & $0.26 \pm 0.03$ & $\mathrm{NA}$ \\
INDO & $\mathrm{NA}$ & $0.29 \pm 0.04$ & 1.11 \\
\hline
\end{tabular}

LH: leaf hexane extract, LC: leaf chloroform extract, LE: leaf ethanol extract, BH: bark hexane extract, BC: bark chloroform extract, BE: bark ethanol extract, NDGA: nordihydroguaiaretic acid, and INDO: indomethacin.

Data were obtained from three independent experiments, each performed in triplicates $(n=9)$, and represented as mean \pm SD.

Values with the same letter are not significantly different $(P<0.05)$ according to Tukey, multiple comparison test.

as well as the increased release of proinflammatory cytokines by macrophages and lymphocytes.

In the 5-LOX assay, chloroform extract of the barks displayed potent enzyme inhibition $\left(\mathrm{IC}_{50}=29.53 \pm 0.03 \mu \mathrm{g} / \mathrm{mL}\right.$ ) which was relatively similar to nordihydroguaiaretic acid $\left(\mathrm{IC}_{50}=29.19 \pm 0.02 \mu \mathrm{g} / \mathrm{mL}\right)$. Ethanol extract of leaves and barks follows through with $\mathrm{IC}_{50}=49.66 \pm 0.02 \mu \mathrm{g} / \mathrm{mL}$ and $\mathrm{IC}_{50}=59.06 \pm 0.07 \mu \mathrm{g} / \mathrm{mL}$, respectively. Thus the potency of activity against 5 -LOX was $\mathrm{BC}>\mathrm{LE}>\mathrm{BE}$ (Table 3 ). According to the 5-LOX enzyme inhibition activity measurement guide by Kamatou et al. [25] and Paraskeva et al. [32] $\left(\mathrm{IC}_{50}<\right.$ $30 \mu \mathrm{g} / \mathrm{mL}$ : good activity; $30<\mathrm{IC}_{50}<80 \mu \mathrm{g} / \mathrm{mL}$ : moderate activity; $\mathrm{IC}_{50}>80 \mu \mathrm{g} / \mathrm{mL}$ : poor activity), chloroform extract of barks of Canarium patentinervium Miq. displays good 5LOX enzyme inhibition activity followed by moderate activity by ethanol extract of leaves and barks.

$\mathrm{COX}$ (prostaglandin $\mathrm{H}_{2}$ synthase) inhibition is the mechanism of action of most NSAIDS. COX-1 is a constitutive form of the enzyme that has been linked to the production of physiologically important prostaglandins that may play a role in homeostasis (gastric, renal, etc.). COX-2 is a form of the enzyme that is inducible by cytokines and growth factors. Induction of COX-2 is linked to inflammatory cell types and tissues. There is an ongoing effort to identify compounds that might inhibit COX-2 in preference to COX-1 since such an agent may be safer and perhaps more efficacious. In the COX assay, only ethanol extract of leaves and barks exhibited $\mathrm{IC}_{50}$ below $100 \mu \mathrm{g} / \mathrm{mL}$. Ethanol extract of leaves had superior COX-1 inhibition $\left(\mathrm{IC}_{50}=0.60 \pm 0.01 \mu \mathrm{g} / \mathrm{mL}\right)$ compared to COX-2 inhibition $\left(\mathrm{IC}_{50}=1.07 \pm 0.01 \mu \mathrm{g} / \mathrm{mL}\right)$, whereas the barks had superior COX-2 inhibition $\left(\mathrm{IC}_{50}=\right.$ $9.39 \pm 0.03 \mu \mathrm{g} / \mathrm{mL})$ as opposed to COX-1 $\left(\mathrm{IC}_{50}=11.41 \pm\right.$ $0.03 \mu \mathrm{g} / \mathrm{mL}$ ). According to Burnett et al. [36], Yang et al. [37], and Jim and Mark [38], a COX-1 selective inhibitor will have ratio $<1$, whereas a COX-2 selective inhibitor will have ratio of $>1$. In this study ethanol extract of bark was COX-2 selective, while the leaves were COX-1 selective.

The results above are a good indication of a potential anti-inflammatory action of these extracts on the COX and 5-LOX system. The actual efficacy of an anti-inflammatory activity needs to be validated by testing the isolated bioactive compounds in a cell-based environment (in vitro) and in a biological system (in vivo). Additional studies are ongoing to isolate the bioactive compounds from the active fractions.

\section{Conclusion}

A combination of anti-inflammatory and antioxidant activities constitutes a good indication on potential anti-inflammatory activity of drug $[39,40]$; keeping this in minds the ethanol extract of the plant warrants further studies by isolation of bioactive components. The pathway mechanism for the dual inhibition of the bioactive component against 5-LOX and COX needs to be investigated. The clinical significance of these data is quite clear that they support a role for Canarium patentinervium Miq. (Burseraceae Kunth.) as a source of lead compounds in the management of inflammatory diseases.

\section{Conflict of Interests}

The authors declare that they have no conflict of interests.

\section{References}

[1] A. C. Brooks, C. J. Whelan, and W. M. Purcell, "Reactive oxygen species generation and histamine release by activated mast cells: modulation by nitric oxide synthase inhibition," British Journal of Pharmacology, vol. 128, no. 3, pp. 585-590, 1999.

[2] S. Fiorucci, R. Meli, M. Bucci, and G. Cirino, "Dual inhibitors of cyclooxygenase and 5-lipoxygenase. A new avenue in antiinflammatory therapy?" Biochemical Pharmacology, vol. 62, no. 11, pp. 1433-1438, 2001.

[3] T. Kirchner, B. Aparicio, D. C. Argentieri, C. Y. Lau, and D. M. Ritchie, "Effects of tepoxalin, a dual inhibitor of cyclooxygenase/5-lipoxygenase, on events associated with NSAIDinduced gastrointestinal inflammation," Prostaglandins Leukotrienes and Essential Fatty Acids, vol. 56, no. 6, pp. 417-423, 1997.

[4] F. Celotti and T. Durand, "The metabolic effects of inhibitors of 5-lipoxygenase and of cyclooxygenase 1 and 2 are an advancement in the efficacy and safety of anti-inflammatory therapy," 
Prostaglandins and Other Lipid Mediators, vol. 71, no. 3-4, pp. 147-162, 2003.

[5] M. M. Skelly and C. J. Hawkey, "Cox-lox inhibition: current evidence for an emerging new therapy," International Journal of Clinical Practice, vol. 57, no. 4, pp. 301-304, 2003.

[6] J. M. Alvaro-Gracia, "Licofelone: clinical update on a novel LOX/COX inhibitor for the treatment of osteoarthritis," Rheumatology, vol. 43, supplement 1, pp. 21-25, 2004.

[7] K. Brune, "Safety of anti-inflammatory treatment: new ways of thinking," Rheumatology, vol. 43, supplement 1, pp. 16-20, 2004.

[8] M. R. Sulaiman, A. Mohd Padzil, K. Shaari et al., "Antinociceptive activity of melicope ptelefolia ethanolic extract in experimental animals," Journal of Biomedicine and Biotechnology, vol. 2010, Article ID 937642, 6 pages, 2010.

[9] C. Wiart, S. Mogana, S. Khalifah et al., "Antimicrobial screening of plants used for traditional medicine in the state of Perak, Peninsular Malaysia," Fitoterapia, vol. 75, no. 1, pp. 68-73, 2004.

[10] R. Mogana, T. D. Bradshaw, K. T. Jin, and C. Wiart, "In Vitro antitumor potential of Canarium patentinervium Miq.", Academic Journal of Cancer Research, vol. 4, no. 1, pp. 1-4, 2011.

[11] R. Mogana, K. Teng-Jin, and C. Wiart, "In vitro antimicrobial, antioxidant activities and phytochemical analysis of Canarium patentinervium Miq. from Malaysia," Biotechnology Research International, vol. 2011, Article ID 768673, 5 pages, 2011.

[12] I. H. Burkhill, A Dictionary of the Economic Products of the Malay Peninsula, Ministry of Agriculture and Co-Operatives, Kuala Lumpur, Malaysia, 1966.

[13] V. L. Singleton and J. A. Rossi, "Colorimetry of total phenolics with phosphomolybdic-phosphotungstic acid reagents," American Journal of Enology and Viticulture, vol. 16, pp. 144-158, 1965.

[14] T. Froehlicher, T. Hennebelle, F. Martin-Nizard et al., "Phenolic profiles and antioxidative effects of hawthorn cell suspensions, fresh fruits, and medicinal dried parts," Food Chemistry, vol. 115, no. 3, pp. 897-903, 2009.

[15] N. J. Miller, C. Rice-Evans, M. J. Davies, V. Gopinathan, and A. Milner, "A novel method for measuring antioxidant capacity and its application to monitoring the antioxidant status in premature neonates," Clinical Science, vol. 84, no. 4, pp. 407-412, 1993.

[16] C. A. Rice-Evans, "Chapter 5: formation of free radicals and mechanisms of action in normal biochemical processes and pathological states," New Comprehensive Biochemistry, vol. 28, pp. 131-153, 1994.

[17] R. Re, N. Pellegrini, A. Proteggente, A. Pannala, M. Yang, and C. Rice-Evans, "Antioxidant activity applying an improved ABTS radical cation decolorization assay," Free Radical Biology and Medicine, vol. 26, no. 9-10, pp. 1231-1237, 1999.

[18] I. F. F. Benzie and J. J. Strain, "The ferric reducing ability of plasma (FRAP) as a measure of "antioxidant power": the FRAP assay," Analytical Biochemistry, vol. 239, no. 1, pp. 70-76, 1996.

[19] A. Dapkevicius, R. Venskutonis, T. A. Van Beek, and J. P. H. Linssen, "Antioxidative activity of extracts obtained by different isolation procedures from some aromatic herbs grown in Lithuania," Journal of Science of Food and Agriculture, vol. 77, pp. 140-146, 1998.

[20] S. Habtemariam and C. Jackson, "Antioxidant and cytoprotective activity of leaves of Peltiphyllum peltatum (Torr.) Engl," Food Chemistry, vol. 105, no. 2, pp. 498-503, 2007.

[21] P. Dhar, A. B. Tayade, P. K. Bajpai et al., "Antioxidant capacities and total polyphenol contents of hydro-ethanolic extract of phytococktail from trans-himalaya," Journal of Food Science, vol. 77, no. 2, pp. C156-C161, 2012.
[22] Switzerland, "SOD determination kit," Sigma-Aldrich Chemie $\mathrm{GmbH}$.

[23] A. Karadag, B. Ozcelik, and S. Saner, "Review of methods to determine antioxidant capacities," Food Analytical Methods, vol. 2, no. 1, pp. 41-60, 2009.

[24] S. Baylac and P. Racine, "Inhibition of 5-lipoxygenase by essential oils and other natural fragment extracts," International Journal of Aromatherapy, vol. 13, no. 2-3, pp. 138-142, 2003.

[25] G. P. P. Kamatou, A. M. Viljoen, and P. Steenkamp, "Antioxidant, antiinflammatory activities and HPLC analysis of South African Salvia species," Food Chemistry, vol. 119, no. 2, pp. 684-688, 2010.

[26] J. K. Gierse and C. M. Koboldt, "Cyclooxygenase assays," Current Protocols in Pharmacology, unit 3.1, 1998.

[27] J. K. Moon and T. Shibamoto, "Antioxidant assays for plant and food components," Journal of Agricultural and Food Chemistry, vol. 57, no. 5, pp. 1655-1666, 2009.

[28] R. L. Prior, X. Wu, and K. Schaich, "Standardized methods for the determination of antioxidant capacity and phenolics in foods and dietary supplements," Journal of Agricultural and Food Chemistry, vol. 53, no. 10, pp. 4290-4302, 2005.

[29] D. Huang, O. U. Boxin, and R. L. Prior, "The chemistry behind antioxidant capacity assays," Journal of Agricultural and Food Chemistry, vol. 53, no. 6, pp. 1841-1856, 2005.

[30] A. V. Badarinath, K. Mallikarjuna Rao, C. Madhu Sudhana Chetty, S. Ramkanth, T. V. S. Rajan, and K. Gnanaprakash, "A review on In-vitro antioxidant methods: comparisions, correlations and considerations," International Journal of PharmTech Research, vol. 2, no. 2, pp. 1276-1285, 2010.

[31] M. J. T. J. Arts, J. S. Dallinga, H. P. Voss, G. R. M. M. Haenen, and A. Bast, "A critical appraisal of the use of the antioxidant capacity (TEAC) assay in defining optimal antioxidant structures," Food Chemistry, vol. 80, no. 3, pp. 409-414, 2003.

[32] M. P. Paraskeva, S. F. van Vuuren, R. L. van Zyl, H. Davids, and A. M. Viljoen, "The in vitro biological activity of selected South African Commiphora species," Journal of Ethnopharmacology, vol. 119, no. 3, pp. 673-679, 2008.

[33] K. Robards, P. D. Prenzler, G. Tucker, P. Swatsitang, and W. Glover, "Phenolic compounds and their role in oxidative processes in fruits," Food Chemistry, vol. 66, no. 4, pp. 401-436, 1999.

[34] A. Rojas, L. Hernandez, R. Pereda-Miranda, and R. Mata, "Screening for antimicrobial activity of crude drug extracts and pure natural products from Mexican medicinal plants," Journal of Ethnopharmacology, vol. 35, no. 3, pp. 275-283, 1992.

[35] A. A. Spector, J. A. Gordon, and S. A. Moore, "Hydroxyeicosatetraenoic acids (HETEs)," Progress in Lipid Research, vol. 27, no. 4, pp. 271-323, 1988.

[36] B. P. Burnett, Q. Jia, Y. Zhao, R. M. Levy, and S. Chen, "A medicinal extract of Scutellaria baicalensis and Acacia catechu acts as a dual inhibitor of cyclooxygenase and 5-lipoxygenase to reduce inflammation," Journal of Medicinal Food, vol. 10, no. 3, pp. 442-451, 2007.

[37] M. H. Yang, K. D. Yoon, Y. W. Chin, J. H. Park, and J. Kim, "Phenolic compounds with radical scavenging and cyclooxygenase2 (COX-2) inhibitory activities from Dioscorea opposita," Bioorganic and Medicinal Chemistry, vol. 17, no. 7, pp. 26892694, 2009.

[38] E. R. Jim and G. P. Mark, "Autacoids and antiinflmmatory drugs," in Veterinary Pharmacology \& Therapeutics, pp. 470472, John Wiley \& Sons, 9th edition, 2009. 
[39] C. W. Choi, S. C. Kim, S. S. Hwang et al., "Antioxidant activity and free radical scavenging capacity between Korean medicinal plants and flavonoids by assay-guided comparison," Plant Science, vol. 163, no. 6, pp. 1161-1168, 2002.

[40] G. A. Alitonou, F. Avlessi, D. K. Sohounhloue, H. Agnaniet, J. M. Bessiere, and C. Menut, "Investigations on the essential oil of Cymbopogon giganteus from Benin for its potential use as an anti-inflammatory agent," International Journal of Aromatherapy, vol. 16, no. 1, pp. 37-41, 2006. 

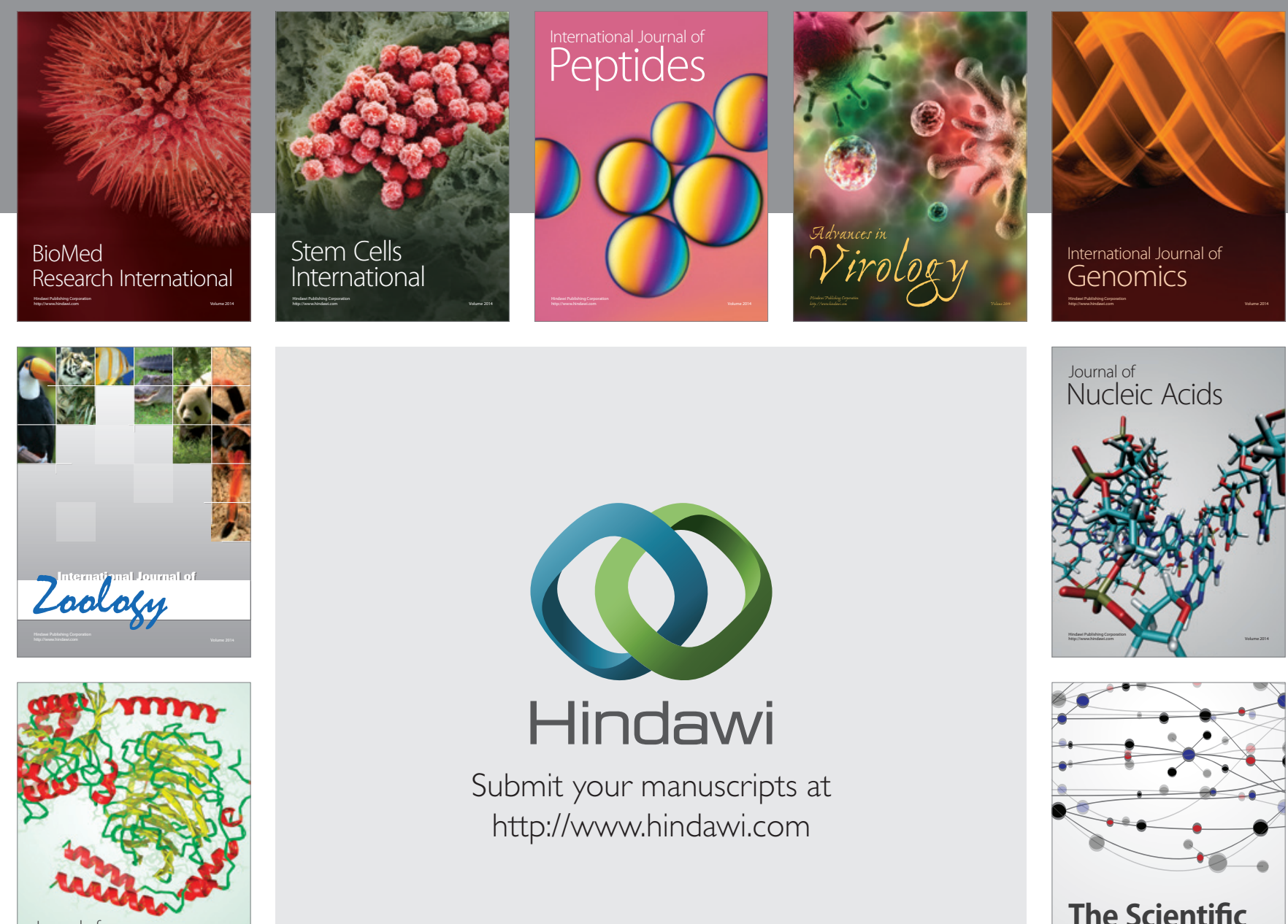

Submit your manuscripts at

http://www.hindawi.com

Journal of
Signal Transduction
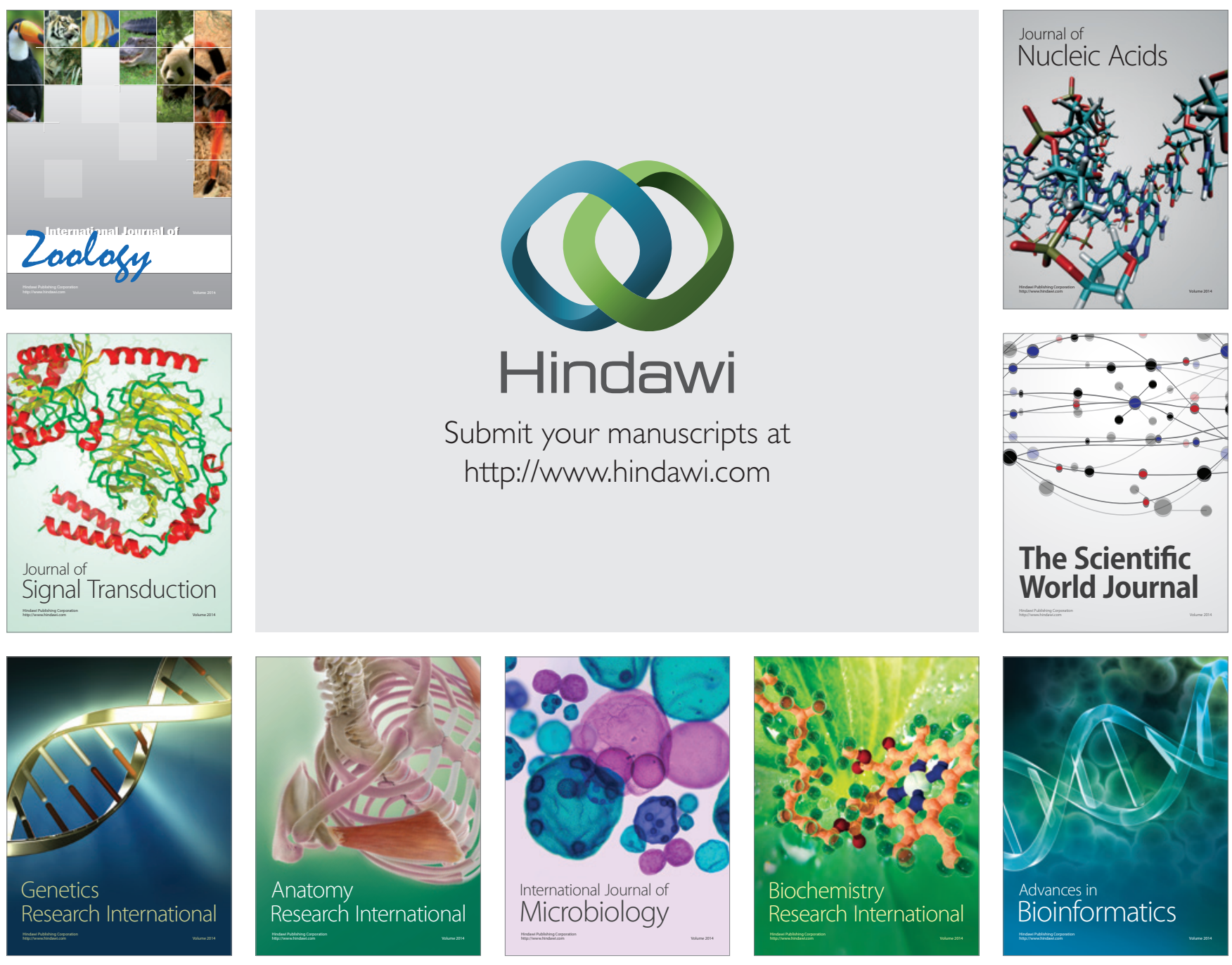

The Scientific World Journal
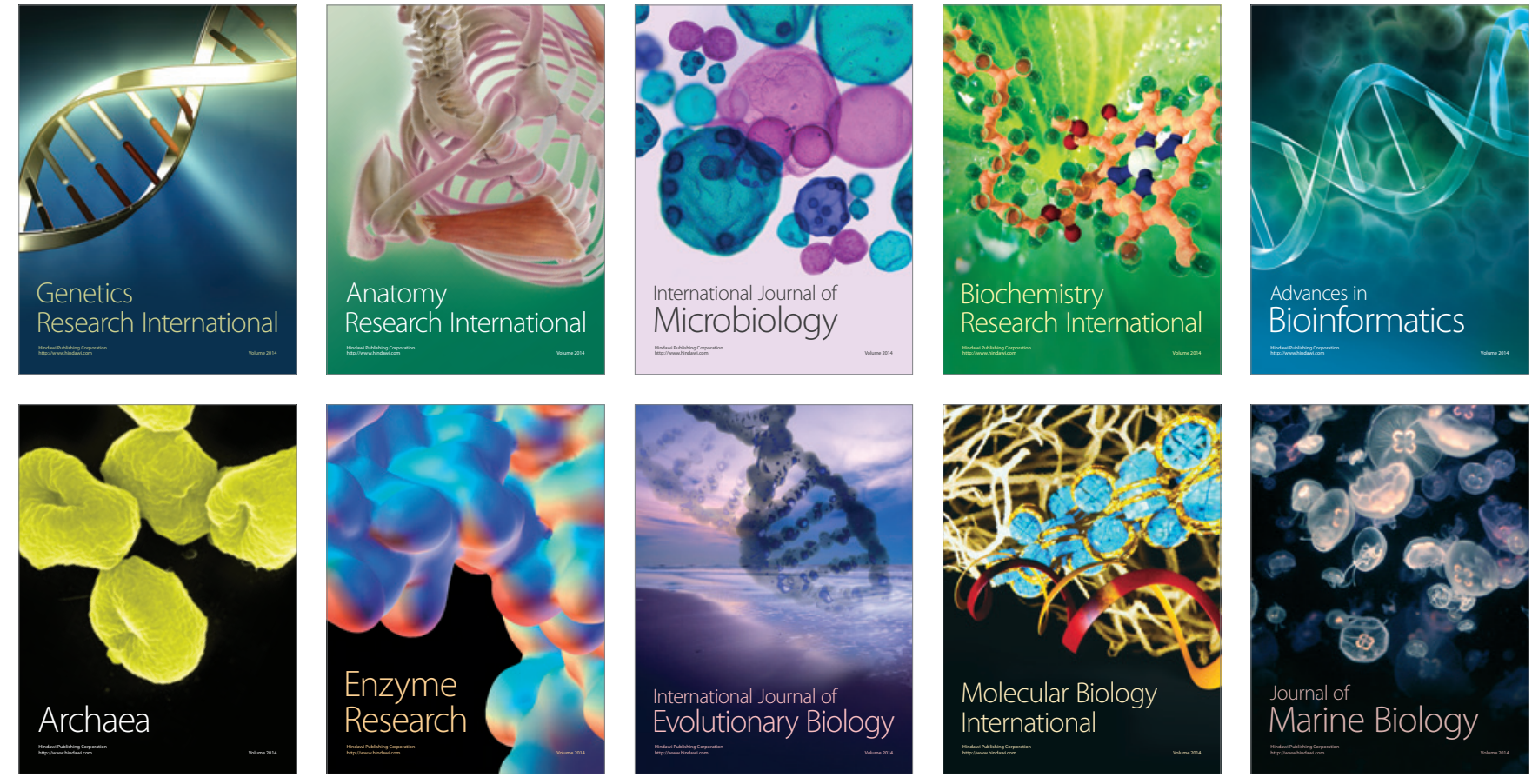